\title{
Environmental assessment of yield improvements obtained by the use of the enzyme phospholipase in mozzarella cheese production
}

\author{
Per H. Nielsen • Erik Høier
}

Received: 7 December 2007 / Accepted: 24 November 2008 /Published online: 16 December 2008

(C) The Author(s) 2008. This article is published with open access at Springerlink.com

\begin{abstract}
Background, aim and scope Phospholipase is an enzyme which is able to increase the yield of cheese in, for instance, mozzarella production. Milk production is the most important source of environmental impacts in cheese production and it is obvious to assume that the milk saving that comes with the use of phospholipase reduces the overall environmental impacts of the final product. Production of industrial phospholipase is, however, also associated with environmental burdens and it is not known whether and to what extent the use of phospholipase is justified by overall environmental improvements. The aim of the present study is therefore to assess the environmental impacts that come with the use of industrial phospholipase in mozzarella production and compare with the savings that come with the avoided milk production. The study addresses mozzarella production in Denmark.

Methods LCA is used as analytical tool and environmental modelling is facilitated in SimaPro 7.1.8 LCA software. Yield improvements refer to full scale industrial application of phospholipase in cheese industry. The study is a comparative analysis and a marginal and market-oriented approach is taken. The study addresses contribution to global warming, acidification, nutrient enrichment, photo-
\end{abstract}

Responsible editor: Niels Jungbluth

P. H. Nielsen $(\square)$

Novozymes A/S,

Krogshøjvej 36,

2880 Bagsværd, Denmark

e-mail: phgn@novozymes.com

E. Høier

Chr. Hansen A/S,

Bøge Allé 10-12,

2970 Hørsholm, Denmark chemical smog formation, energy consumption and use of agricultural land. Estimation of environmental impact potentials is based on Eco-indicator 95 v.2.1 equivalency factors. Toxicity is addressed by qualitative means.

Results The environmental impacts induced by phospholipase production are small compared with the savings obtained by reduced milk consumption for mozzarella production when all impact indicators are considered. Sensitivity analyses and data quality assessments indicate that this general outcome of the study is robust, although results at the more detailed level are the subject of much variation and uncertainty.

Discussion Transport of the enzyme from producer to mozzarella producer is insignificant and the general outcome of the study is considered applicable to other regions of the world where milk is produced in modern milk production systems. Conclusions Use of phospholipase as a yield improvement factor is a means of reducing environmental impact of mozzarella production.

Recommendations and perspectives The total annual global warming mitigation potential of phospholipase used in production of mozzarella and other pasta filata products is in the order of $7 \times 10^{8} \mathrm{~kg} \mathrm{CO}$ equivalents. The use of phospholipase is driven by overall cost savings and it is therefore recommended that the enzyme should be given attention as a cost-efficient means of reducing greenhouse gas emissions.

Keywords Biotechnology · Dairy · Enzymatic · LCA . Milk · Pasta filata

\section{Introduction}

Retention of dry-matter constituents in milk has been a major focus point in optimisation efforts in the cheese 
industry for many years. Most efforts have been on processing principles and hardware, but the yield improvements obtained in the past decade have only been minor (Høier et al. 2006).

The enzyme phospholipase A1 (De Maria et al. 2007), which has recently become commercially available to the cheese industry as an industrially produced product, increases the fat retention considerably during cheesemaking and yield improvements in the range of $0.7-3.8 \%$ have been observed in full-scale production of pasta filata cheese types such as mozzarella and provolone (Lilbæk et al. 2006; Høier et al. 2006). Use of enzyme technology has therefore become an interesting supplement to the more hardware-oriented efforts to increase yield that have been seen in pasta filata factories in the past few years.

The enzyme reacts with phospholipids in the milk by hydrolyzing the fatty acid and generating a free fatty acid and a lyso-phospholipid. The mechanism of yield improvement is not fully understood, but better oil/water emulsification of lyso-phospholipids than phospholipids or interaction of lyso-phospholipids with protein have been proposed (see Høier et al. 2006).

Berlin (2002) has documented that milk production is the most important source of environmental impacts in cheese production and it is obvious to assume that the milk savings that come with the use of phospholipase in cheesemaking reduces the overall environmental impacts of the final cheese product. Production of industrial enzymes is, however, also associated with environmental burdens (Nielsen et al. 2007) and it is not known whether and to what extent the use of phospholipase is justified by overall environmental improvements.

The goal of the present study was therefore to assess the environmental burdens of the supplements that come with the use of phospholipase and compare with the milk savings that come with the better yield of cheese.

The considered phospholipase is produced by microbial fermentation and implemented in the market as a commercial product (YieldMAX PL ${ }^{\mathrm{TM}}$ ) by Novozymes A/S and Chr. Hansen $\mathrm{A} / \mathrm{S}$ in collaboration.

\section{Materials and methods}

The study is based on life cycle assessment (LCA) principles, where all significant processes in the product chain from raw material extraction through production and use to final disposal are included. The LCA is performed according to the method described by Wenzel et al. (1997) and environmental modelling is facilitated in SimaPro 7.1.8 LCA software. The study is a comparative analysis of the impacts that are generated when phospholipase is introduced in cheese production with the impacts that are avoided as a result of the milk saving. Consequently, a marginal and market-oriented approach is taken in the study and co-product issues are handled by including the products that co-products replace in the market (expansion of the product system, ISO 2006), see Ekvall and Weidema (2004).

\section{Scope}

\subsection{Geographical scope and time perspective}

The study focuses on mozzarella produced in Denmark. Yield improvements obtained by phospholipase application are to a large extent determined by the fat content of the final cheese and mozzarella products with $40 \%$ and $50 \%$ fat (dry matter basis) have been addressed. The considered industrial phospholipase product (YieldMAX PLTM) originates from Fusarium venenatum. It is produced in Denmark by submerged fermentation in an Aspergillus oryzae production strain.

Mozzarella can be produced at the same production line with and without YieldMAX application and there is no capital investments associated with a switch between the two production methods. Switching from one system to another has therefore no long-term implication. The time perspective of the study is therefore now and in the next few years.

\subsection{Functional unit}

The functional unit of the study is the production of $1,000 \mathrm{~kg}$ mozzarella with fixed fat and protein content.

\subsection{System boundaries}

Main system boundaries of the study are shown in Fig. 1.

It is assumed that $10,000 \mathrm{~kg}$ milk $(4.5 \%$ fat and $3.4 \%$ protein) is used to produce $1,000 \mathrm{~kg}$ mozzarella $(40 \%)$ in the reference situation without phospholipase application and that the addition of $0.68 \mathrm{~kg}$ phospholipase saves $1.8 \%$ of the cheese milk (Høier et al. 2006), corresponding to $180 \mathrm{~kg}$ milk (see Fig. 1). Furthermore, it is assumed that the fat and protein contents of the final mozzarella product are fixed and that the reduced input of milk leads to a reduced output of fat in the form of butter/whey butter and protein in the whey. The reduced fat and protein outputs are determined by mass balance over the entire mozzarella production process (see Fig. 1) and estimated at $8.1 \mathrm{~kg}$ fat and $6.3 \mathrm{~kg}$ protein $(4.5 \%$ and $3.5 \%$ of $180 \mathrm{~kg}$ milk, respectively).

Reduced output of fat from the mozzarella production to the edible fat market leads to an increased demand for 


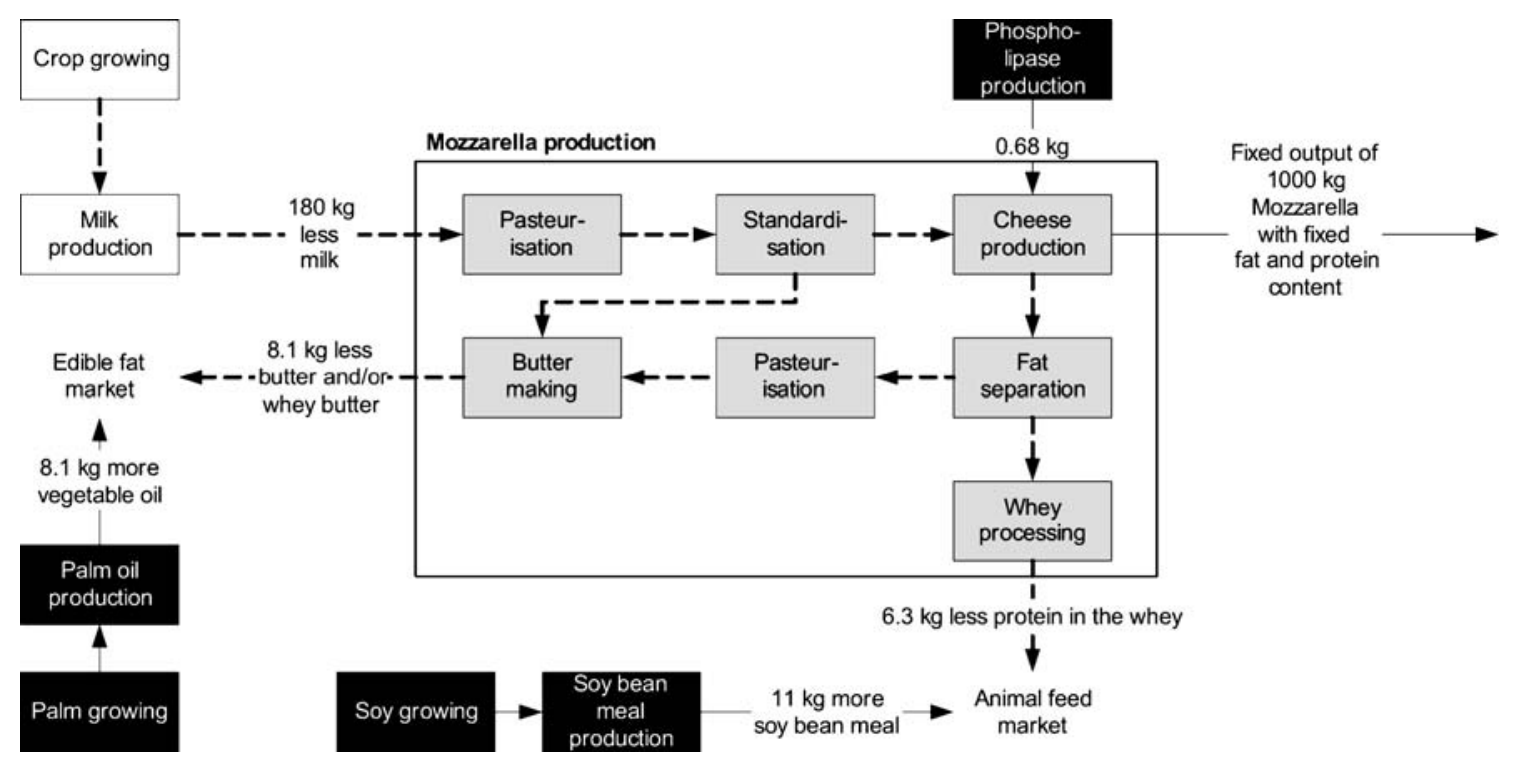

Fig. 1 Main system boundaries of the study. Use of phospholipase in cheese production (see upper right corner) saves milk in mozzarella production (see upper left corner) without changing the quantity or the quality of cheese production (upper right corner). Reduced use of milk in mozzarella production leads to reduced output of fat and protein with the whey. Reduced output of whey fat and whey protein from mozzarella production is compensated for in the market by increased production of edible fat (palm oil) and protein for animal

production (soy bean meal), see lower left corner. Black boxes indicate processes that are induced when phospholipase is used in mozzarella production. White boxes indicate reduced production processes when phospholipase increases the yield. Dotted arrows indicate reduced material streams and full arrows indicate increased material streams. Processes marked with grey boxes are insignificant and disregarded in the study. All data are per 1,000 kg mozzarella with fixed protein and fat content $(40 \%$ fat $)$

alternative edible fat. Vegetable oil and milk fat can replace each other in many applications in food processing and vegetable oil is likely to meet the demand because it is cheap. Palm oil appears to be the marginal vegetable oil (Schmidt and Weidema 2008) and it is assumed that missing output of butter/whey butter from the cheese factory is compensated for by increased palm oil production. It is assumed that butter and vegetable oil replace each other at a 1:1 ratio and the additional palm oil production induced by phospholipase application is estimated at $8.1 \mathrm{~kg}$ $(1,000 \mathrm{~kg} \text { mozzarella })^{-1}$.

Whey protein is used in human food supply and as feed in animal breeding. It is supposed that using whey protein as animal feed is less lucrative than other uses and it is considered likely that a reduction in the protein output from the cheese factory will lead to an increased demand for alternative protein sources in animal breeding. Whey is often used for feeding cattle and the reduced output of protein with the whey is likely to lead to an increased demand for alternative protein sources for the cattle. Soybean meal is a cheap and widely used protein source and it is assumed that soybean meal is the marginal source of feed protein and that increased soybean meal production compensates for the missing output with the whey. It is assumed that whey protein and soybean meal substitute for each other on a digestible protein basis and since the digestibility coefficient of the whey protein for cattle is

about $70 \%$ and $40 \%$ for soybean meal (Møller et al. 2005), it is estimated that about $11 \mathrm{~kg}$ soybean meal compensates for the missing whey protein $\left(6.3 \mathrm{~kg} \cdot 0.70 \cdot 0.40^{-1}\right)$.

Estimates of milk saving and reduced output of protein and fat as a result of phospholipase application have been verified by estimates based on protein and fat conversion ratios in mozzarella production. Similar considerations have been made for 50\% mozzarella with the following assumptions: (1) $8,300 \mathrm{~kg}$ milk is used to produce $1,000 \mathrm{~kg}$ mozzarella (50\%); (2) $3.4 \%$ of the milk is saved when $0.73 \mathrm{~kg}$ phospholipase is used in the production.

Lactose and ash content of the final mozzarella is independent of phospholipase application and is not considered in the study. All data refer to cheese dry matter and a slight moisture increase in the final mozzarella resulting from phospholipase application (Lilbæk et al. 2006) does not influence the results of the study.

The saving of milk for mozzarella production as a result of phospholipase application leads to a range of minor changes in the cheese factory that have not been accounted for in the study: a few percent less cheese milk is pasteurised, a few percent less milk is standardised, a few percent less butter/whey butter is churned, etc. Cheese production is, however, responsible for less than $5 \%$ of the environmental impacts of cheese production (Berlin 2002) and disregarding the small changes in the cheese production is considered insignificant. 


\subsection{Indicators}

The study addresses following environmental impact indicators: global warming, acidification, nutrient enrichment and photochemical smog formation. Except toxicity, these impact indicators are deemed to cover the environmentally essential issues. Contributions to toxicity are not quantified because the available data basis is considered too incomplete and toxicity is evaluated by qualitative means as the best alternative. Particle emission is judged to be linked to energy consumption (see below) in the considered system and is not given particular attention in the study. Emissions of ozone-degrading compounds are insignificant in the considered system and no indicator for stratospheric ozone depletion has been included.

Energy use plays an important role in the considered system and fuel consumption has been aggregated and quantified in terms of 'MJ primary energy carriers'. Enzyme production and milk production are both based on agricultural production and use of agricultural land has been included in the assessment. Other types of land use (mining, construction and infrastructure) are not included in the assessment because they are considered of minor importance in the present context.

In accordance with ISO (2006), the study focuses on the potential environmental effects of emissions because in practice it is impossible to know all sites of emissions and all exposure pathways. Calculation of environmental impact potentials is based on Eco-indicator 95 v.2.1 equivalency factors.

\section{Environmental modelling}

Environmental modelling of phospholipase follows principles described by Nielsen et al. (2007) and includes all electricity, steam and water consumptions, all significant waste treatment processes and $97 \%(w / w)$ of ingredients consumed in production (2006 production records). The phospholipase product is produced in Denmark and shipped via regional distribution centres to the final user. It is assumed that phospholipase is transported $500 \mathrm{~km}$ in a lorry (Ecoinvent 2007).

Phospholipase is packed in 20-1 cans (1.1 kg HDPE). Density of the phospholipase product is $1.13 \mathrm{~kg} \times 1^{-1}$ and the production of $49 \mathrm{~g}$ HDPE $\cdot \mathrm{kg}^{-1}$ phospholipase product is included in the assessment (Ecoinvent 2007). The fate of 201 cans after use is unknown and it is assumed conservatively that $100 \%$ of the cans are disposed in landfill. Contribution to waste generation from cans $\left(33 \mathrm{~g} \cdot(1,000 \mathrm{~kg} \text { mozzarella })^{-1}\right)$ is not given further attention in the assessment.

Environmental modelling of milk is based on LCA food database (2003). Modelling of milk refers to conventional intensive farming practice $\left(>2.3\right.$ livestock units $(\mathrm{LSU}) \times \mathrm{ha}^{-1}$ at farms located on sandy soil. Meat co-produced with the milk has been accounted for by displacing an equivalent quantity of meat from beef cattle (LCA food database 2003; Cederberg and Stadig 2003). Milk quotas in the European Union are phased out in these years (EC 2006) and modelling refers to a milk market without quota regulation. Modelling of palm oil is based on Ecoinvent (2007), although applied co-product allocations have been eliminated and changed to system expansion (Weidema and Wesnæs 2006). Modelling of soy bean meal production is based on Ecoinvent (2007). Conversion of beans into meal and oil is based on LCAfood (2003).

Milk transportation distances and modes of transportation between dairy farms and cheese factory are unknown and conservatively estimated at $50 \mathrm{~km}$ in a lorry (Ecoinvent 2007). Transportation of milk is not a major issue in environmental assessment of milk products (Eide 2002) and the effect of inaccurate transport distances is probably small.

\section{Data quality assessment}

Modelling of the production of phospholipase is based on very detailed up-to-date production information and the quality of the data is considered good. For details, see Nielsen et al. (2007).

Data on milk production are based on very detailed records from a representative sample of Danish farmers and data quality is considered high even though the data are not completely up to date (refer to 2002). Data on palm oil and soybean meal production are considered good.

\section{Results}

The results of the environmental assessment are shown in Fig. 2.

Figure 2 shows that the impacts induced by phospholipase application (black bars) are generally small compared with the avoided impacts that come with the milk saving (white bars). The saved contributions to acidification and nutrient enrichment are relatively high because considerable $\mathrm{NH}_{3}$ and $\mathrm{NO}_{3}{ }^{-}$emissions from the dairy farm are avoided when milk is saved. The avoided contribution to global warming is high compared with the saved fossil energy resources because considerable $\mathrm{CH}_{4}$ and $\mathrm{N}_{2} \mathrm{O}$ emissions are avoided at the dairy farms $\left(\mathrm{CH}_{4}\right.$ and $\mathrm{N}_{2} \mathrm{O}$ are relatively strong greenhouse gases). The distribution of the phospholipase (packaging and transportation) from producer to the final user is unimportant for the final result. 


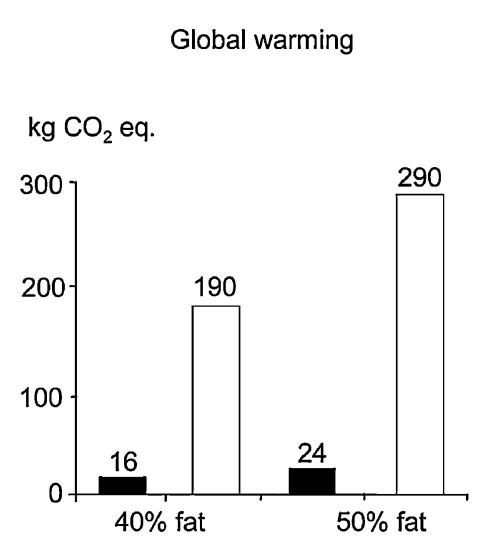

Photochemical smog formation

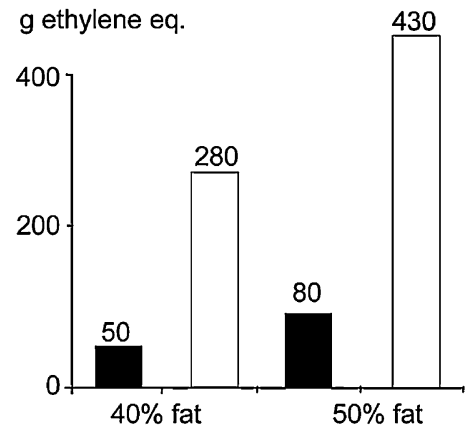

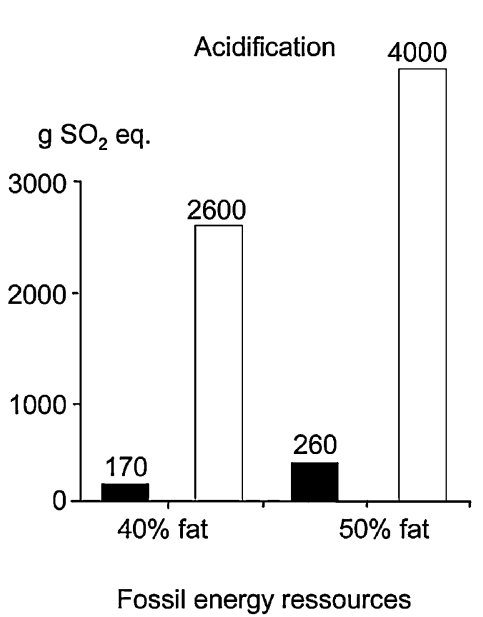

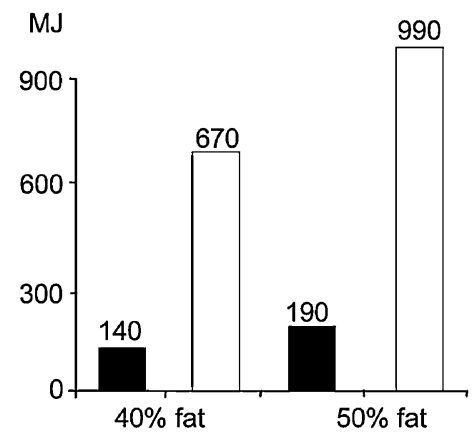

3000

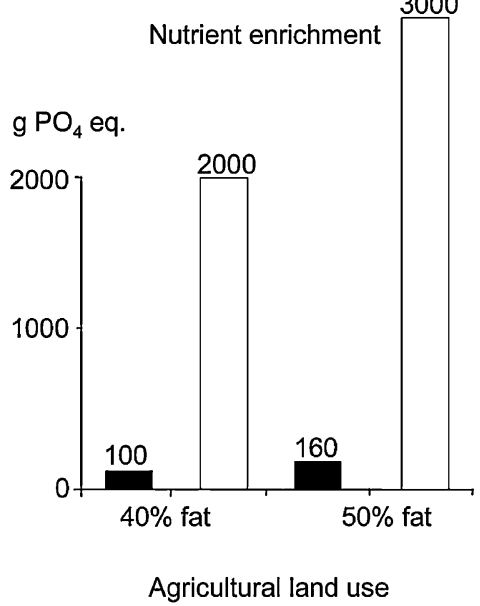

$\mathrm{m}^{2}$.year

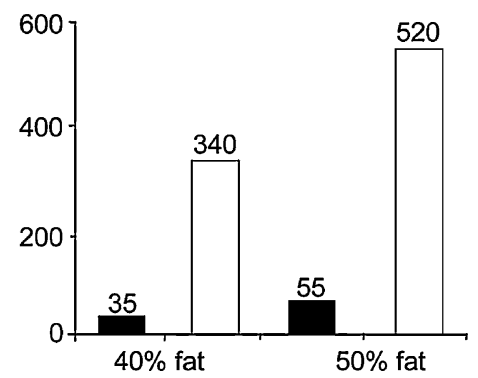

Fig. 2 Added (black bars) and saved (white bars) contributions to environmental impacts when phospholipase is introduced in the production of mozzarella with $40 \%$ and $50 \%$ fat content. Added impacts are due to industrial phospholipase production and increased

\section{Sensitivity analyses}

The present assessment is based on a range of assumptions and simplifications that contribute to the uncertainty of the final outcome of the study. The most important sources of uncertainty relate to the marginal source of vegetable oil and the considered milk production conditions, and the outcomes of sensitivity analyses for these two parameters are provided in the following.

Marginal vegetable oil It has been assumed in the study that the marginal vegetable oil is palm oil (see section 3.3). It cannot, however, be excluded that other types of oil contribute to the marginal supply or will become significant marginal suppliers in the future and the full assessment has been made with rapeseed oil as the marginal vegetable oil instead of palm oil. The results show that phospholipase application remains advantageous in terms of all considered impact categories independently of the switch between vegetable oils, although the margin between added and saved environmental impacts decreases to some extent. production of palm oil and soybean meal. Saved impacts are due to reduced milk production for mozzarella production. All data are given per $1,000 \mathrm{~kg}$ mozzarella

Milk production The assessment refers to milk produced at conventional intensive farms located on sandy soil (section 4). The environmental impacts of milk production vary, however, with many factors such as soil type, animal density and production practice. A sensitivity analysis has therefore been made with a range characteristic combinations of soil type (sandy/sandy loam), animal density (extensive $\left(<1.4 \mathrm{LSU} \cdot \mathrm{ha}^{-1}\right)$ semiintensive (1.4 to $\left.2.3 \mathrm{LSU} \cdot \mathrm{ha}^{-1}\right)$ and intensive $(>2.3$ LSU $\cdot \mathrm{ha}^{-1}$ ) and farming practice (conventional and organic). The results show that phospholipase use is a major advantage in terms of all considered impact categories independently of the considered production methods, although the reduced environmental impacts obtained by the avoided milk production are subject to some variation.

Quantification of avoided soybean meal and palm oil inputs to the system (see Fig. 1) is based on rather uncertain and variable assumptions. However, the contributions of these two products to the overall results of the study are small and the overall results of the study are insensitive to the variation and uncertainty of these parameters. 
Use of system expansion as alternative to co-product allocation in modelling of palm oil production (section 4) has limited influence on the overall results of the study although modelling based on co-product allocation results in a somewhat lower impact of palm oil than modelling based on system expansion.

The distance between the enzyme producer and mozzarella producer is very short and environmental effect of transport turned out to be unimportant for the final result. Sensitivity analyses showed that transport remained unimportant for the final result even if the enzyme was subject to intercontinental transport. For instance less than $1 \%$ of the total contribution to global warming if the mozzarella producer was located in the central USA.

\section{Discussion}

\subsection{Qualitative toxicity assessment}

Contribution to toxicity is likely to be linked to energy use and use of agricultural land because all significant products in the considered system are derived from agricultural production. Energy and agricultural land use induced by phospholipase application is five to ten times lower than savings (see Fig. 2) and it is considered very likely that phospholipase application leads to a net reduction of the contribution toxicity from mozzarella production.

\subsection{Geographical generality of results}

Transport of the phospholipase from the manufacturer to the user is unimportant from an environmental point of view (section 6) and the general observations of the study are in principle applicable anywhere in the world where milk is produced in modern production systems.

\subsection{Quick estimation of environmental improvement}

The environmental improvement achieved by phospholipase application in cheese production is closely linked to the milk saving because the impacts of the phospholipase, vegetable oil and soy bean meal production are relatively small. Environmental improvement in percent is therefore nearly equivalent to the obtained milk saving in percent.

\section{Conclusions}

The use of phospholipase to improve the yield of mozzarella is justified by major advantages in terms of all considered impact categories, global warming, acidifica- tion, nutrient enrichment, photochemical smog formation, energy consumption, use of agricultural land and most likely also toxicity.

The explanation is that a small quantity of phospholipase saves a considerable quantity of milk and that impacts induced by phospholipase production are small compared with the savings obtained by the reduced milk consumption.

Sensitivity analyses of the most uncertain and varying parameters show that magnitudes of environmental advantages are subject to much uncertainty and variation but that the general observation of the phospholipase as an efficient means of limiting the environmental impacts of mozzarella production is robust. Transport of the phospholipase from producer to user is insignificant and the main observations of the study are considered applicable to other regions of the world where milk is produced in modern systems.

\section{Recommendations and perspectives}

Dairy products have a large share of the total environmental impact of products consumed in our society (e.g. Huppes et al. 2006) and environmental improvement of this product group is meaningful also at the larger societal scale.

The global annual pasta filata production is about $3 \times 10^{9} \mathrm{~kg}$ (Chr. Hansen A/S, unpublished market survey). Use of phospholipase reduces the potential contribution to global warming by about $230 \mathrm{~kg} \mathrm{CO}_{2}$ equivalent $\times(1,000 \mathrm{~kg}$ mozzarella $)^{-1}$ (average of $40 \%$ and $50 \%$ product, see Fig. 2), and the total annual $\mathrm{CO}_{2}$ reduction potential is in the order of $7 \times$ $10^{8} \mathrm{~kg} \mathrm{CO} \mathrm{CO}_{2}$ equivalents $\left(3 \times 10^{9} \mathrm{~kg} \cdot 230 \mathrm{~kg} \mathrm{CO}\right.$ equivalent $\left.\times(1,000 \mathrm{~kg} \text { mozzarella })^{-1}\right)$. The use of phospholipase is driven by overall cost savings and it is therefore recommended that the enzyme should be given attention as a cost-efficient means of reducing greenhouse gas emissions.

Acknowledgements The authors are grateful to Kim Christiansen (Danish Standards) who has critically reviewed the background documentation of the study according to the ISO 14044 standards on LCA, to Henriette Øllgaard (Chr. Hansen A/S) and Per Munk Nielsen (Novozymes A/S) who have supported with data and discussions.

Open Access This article is distributed under the terms of the Creative Commons Attribution Noncommercial License which permits any noncommercial use, distribution, and reproduction in any medium, provided the original author(s) and source are credited.

\section{References}

Berlin J (2002) Environmental life cycle assessment (LCA) of Swedish semi-hard cheese. Int Dairy J 12:939-953

Cederberg C, Stadig M (2003) System expansion and allocation in life cycle assessment of milk and beef production. Int J Life Cycle Assess 8:350-356 
De Maria L, Vind J, Oxenbøll KM, Svendsen A, Patkar S (2007) Phospholipases and their industrial applications. Appl Microbiol Biotechnol 74:290-300

EC (2006) Milk and milk products in the European Union. European Commission, Directorate-General for Agriculture and Rural Development. ISBN 92-79-02199-0. http://ec.europa.eu/agriculture/ publi/fact/milk/2007_en.pdf

Ecoinvent (2007) The Ecoinvent Data Base v2.0. Swiss Centre for Life Cycle Inventories

Eide MH (2002) Life cycle assessment (LCA) of industrial milk production. Int J Life Cycle Assess 7:115-126

Ekvall T, Weidema BP (2004) System boundaries and input data in consequential life cycle inventory analysis. Int $\mathrm{J}$ Life Cycle Assess 9:161-171

Høier E, Lilbæk H, Broe ML, Sørensen NK (2006) Enhancing cheese yield by phospholipase treatment of cheese milk. Aust J Dairy Technol 61:179-182

Huppes G, Koning A, Suh S, Heijungs R, Oers L, Nielsen P, Guinée JB (2006) Environmental impacts of consumption in the European Union-high-resolution input-output tables with detailed environmental extensions. J Indust Ecol 10:129-146
ISO (2006) Environmental management-life cycle assessmentrequirements and guidelines. ISO 14044, first edition

LCA food database (2003) LCAfood database. www.lcafood.dk

Lilbæk HM, Broe ML, Høier E, Fatum TM, Ipsen R, Sørensen NK (2006) Improving the yield of mozzarella cheese by phospholipase treatment of milk. J Dairy Sci 89:4114-4125

Møller J, Thøgersen R, Helleshøj ME, Weisbjerg MR, Søegaard K, Hvelplund T (2005) Fodermiddeltabel 2005, Dansk kvæg. Rapport no. 112, Danish Agricultural Advisory Service (in Danish with English translations)

Nielsen PH, Oxenbøll KM, Wenzel H (2007) Cradle-to-gate environmental assessment of enzyme products produced industrially in Denmark by Novozymes A/S. Int J Life Cycle Assess 12:432-438

Schmidt JH, Weidema BP (2008) Shift in the marginal supply of vegetable oil. Int J Life Cycle Assess 13:235-239

Weidema B, Wesnæs M (2006) Marginal production routes and co-product allocation for alcohol etoxylate from palm oil and palm kernel oil. 2.-0 LCA consultants. http://lca-net.com/files/alchohol_etoxylates.zip

Wenzel H, Hauschild M, Alting L (1997) Environmental assessment of products. Volume 1: Methodology, tools and case studies in product development. Chapman and Hall 